\title{
Subregional Integration in East Central Europe : Strategies in the In-Between Sphere
}

\section{Miklóssy, Katalin}

Palgrave Macmillan

2020-08-31

Miklóssy , K 2020 , Subregional Integration in East Central Europe : Strategies in the In-Between Sphere . in M Broad \& S Kansikas (eds), European Integration Beyond Brussels : Unity in East and West Europe Since 1945 . Security, Conflict and Cooperation in the Contemporary World, Palgrave Macmillan , Cham , pp. 269-290 . https://doi.org/10.1007/978-3-030-45445-6_12

http://hdl.handle.net/10138/321219

https://doi.org/10.1007/978-3-030-45445-6_12

acceptedVersion

Downloaded from Helda, University of Helsinki institutional repository.

This is an electronic reprint of the original article.

This reprint may differ from the original in pagination and typographic detail.

Please cite the original version. 


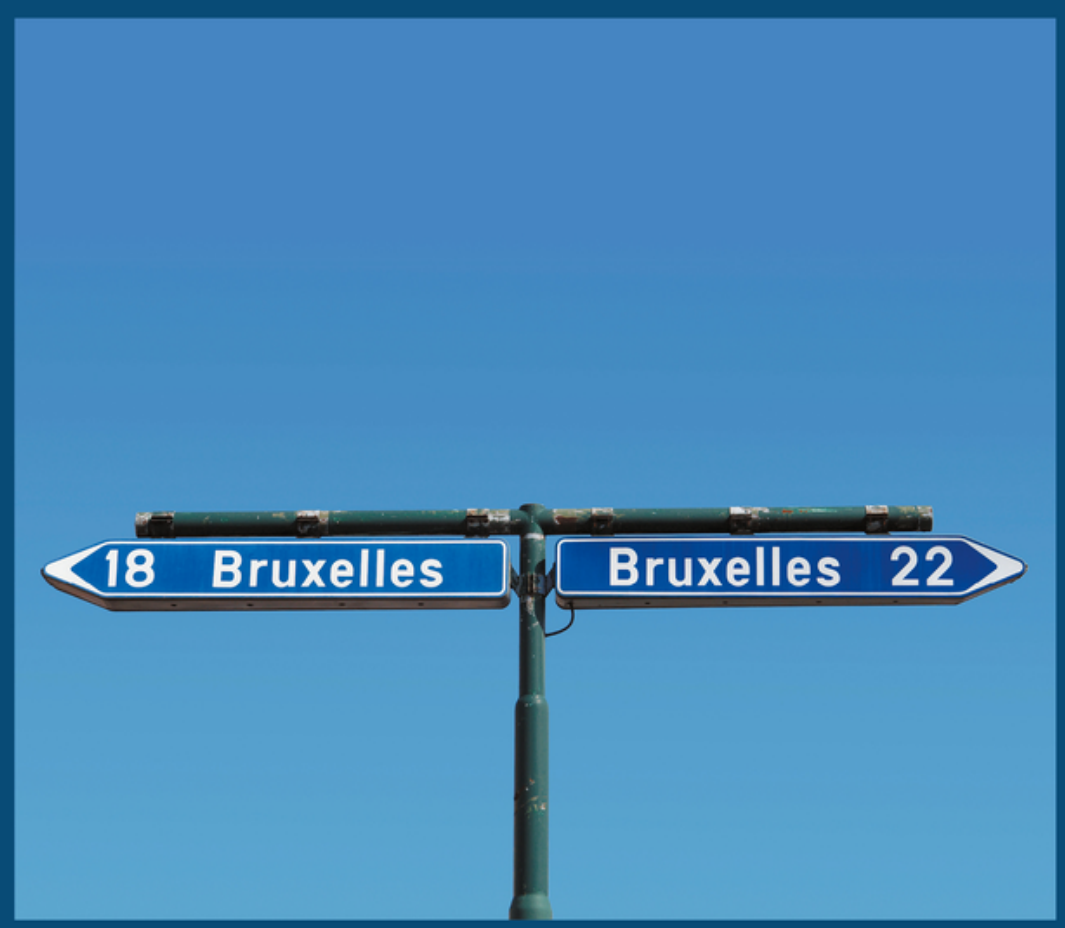

\section{European Integration} Beyond Brussels Unity in East and West Europe since 1945 


\section{Chapter 12}

Subregional Integration in East Central Europe: Strategies in the In-Between Sphere Katalin Miklóssy (University of Helsinki)

Interpretations of the significance of East Central European (ECE) alliances have changed over the past few decades reflecting, first and foremost, the degree of support for the European Union (EU) shown by Poland, the Czech Republic, Slovakia and Hungary - today often referred to as the Visegrád 4 (V4). During the postCommunist transition period, subregional organisations such as the Visegrád union or the Central European Initiative (CEI) were discussed primarily within the context of the EU, framed by the widespread use of the slogan 'Back to Europe'.$^{1}$ In this narrative, subregional integration was pictured as a shared effort by former Eastern Bloc countries to align themselves with the advanced societies of Western Europe. ${ }^{2}$ Since the mid-2010s, by contrast, the Visegrád alliance has been reflected upon as a 'special club' kept together only by its members' critical stance towards the EU. Particularly after the migration crisis of 2015, the V4 was depicted as a quarrelsome bunch of countries lacking plausible common interests. ${ }^{3}$ While historically the EU supported

\footnotetext{
${ }^{1}$ While EU documents and those of the East Central European organisations and states employ the term 'regional' for describing ECE cooperation, I intend to maintain the distinction used generally in this volume reflecting on the EU integration as 'regional' and ECE activities as 'subregional'.

2 Mikko Lagerspetz, 'Postsocialism as a Return: Notes on a Discursive Strategy', East European Politics and Societies 13, no. 2 (1999): 377-90; Heather Grabbe and Kristy Hughes, 'Central and Eastern European Views on EU Enlargement: Political Debates and Public Opinion', in Karen Henderson (ed.), Back to Europe (London and New York: Routledge, 2004), 185-202. See also Martin Dangerfield, 'V4: A New Brand for Europe? Ten Years of Post-Accession Regional Cooperation in Central Europe', Poznan University of Economic Review 14, no. 4 (2014): 71-90.

${ }^{3}$ Benjamin Cunnigham, 'Visegrad's Illusory Union', Politico (16 September 2016), available at https://www.politico.eu/article/poland-hungary-czech-republic-slovakia-visegrads-illusoryunion-bratislava-summit-eu-migration-orban-fico-sobotka-szydlo (accessed 30 October 2019); Robert Anderson, 'Visegrad: Macron Plays Divide and Rule in Central Europe', BNE - Intellinews (24 August 2017), available at https://www.intellinews.com/visegrad-macron-plays-divide-andrule-in-central-europe-127732/ (accessed 30 October 2019); Lili Bayer, 'Unity of Central Europe's Visegrad Group Under Strain', Politico (31 August 2017), available at https://www.politico.eu/article/unity-of-central-europes-visegrad-group-under-strain/ (accessed 30 October 2019).
} 
subregional development as one of the key components of its cohesion policy, it seems that subregional integration might challenge the paramount goals of EU unity. ${ }^{4}$

This chapter uses a different angle to evaluate the role and working mechanism of subregional entities, which in East Central Europe have an equally long, if not longer, history than other European regional ventures. It is therefore important to investigate what kind of relevance the legacy of the subregional option bares on the countries' contemporary national and EU choices. This study claims that we need more research on the complex and simultaneous interaction of multiple levels: between the European and subregional spheres, between the subregional and national stages, and between the national and EU levels.

Hence, our central questions are: How did the East Central European V4 states navigate between these different levels, and what was the main role of the subregional level in comparison to the European framework? What was the incentive to collaborate and what kind of institutions and modus operandi they created for that purpose? To answer these questions, the chapter will first take a look at the historical roots of ECE collaboration, then discuss how the legacy of past alliances can be seen in the post-communist drive to establish parallel organisations and why parallelism was necessary in the first place. Finally, it will analyse how the EU has reacted to subregional integration during and after the accession of the V4, and what kind of interactive dynamics the attitudes of the EU launched in the evolution of subregional affinity.

The article makes three main arguments. First, subregionality, despite its transnational surface, actually emphasises the national agenda and turns it into a spatially extended transnational nationalism ${ }^{5}$. Second, the longue durée perspective reveals that subregionalism plays a central role in preserving sovereignty and integrity, which is why the ECE countries have been ready to recalibrate their national interests

\footnotetext{
${ }^{4}$ European Commission, 'History of the Regional Policy', available at https://ec.europa.eu/regional policy/en/policy/what/history/ (accessed 30 October 2019).

${ }^{5}$ See also for instance Riva Kastoryano, 'Transnational Nationalism: Redefining Nation and Territory', in Seyla Benhabib, Ian Shapiro and Danilo Petranovich (eds.), Identities, Affiliations and Allegiances (Cambridge: Cambridge University Press, 2007); Devashree Gupta, 'Nationalism Across Borders; Transnational Nationalist Advocacy in the European Union', Comparative European Politics, 6 (2008): 61-80.
} 
in order to reach a common ground for the sake of subregional unity. Third, the most fluent and enduring collaboration has been achieved when subregional formations are historically rooted and emerged due to similar factors of development.

The theoretical starting point is based on the claim that East Central Europe represents a double 'in-between-ness': an intersection of horizontal and vertical intermediary spaces. Horizontally, this area is situated at a crossroads where Eastern (mostly Russian) and Western (mostly German) influences have mixed and great power interests clashed over centuries. ${ }^{6}$ Vertically, the subregional level serves as a mediator between the national and external and/or supranational stages and has a profound impact on how the national and international spheres interact with each other. I argue that horizontal in-between-ness creates the spatial context for the subregional actors to organise, establish institutions, invent short-term strategies and generate long-term plans. However, the vertical in-between-ness provides the ultimate means to transform horizontal geopolitical limitations into leverage. The shared experience of navigating between this double orientation created common discourses and policy practices through which the regional actors emphasised either normative-formal connections (such as institutional linkages and formal networks) or symbolic-informal relatedness (such as ideological-cultural affinity, memories, public consciousness). ${ }^{7}$

The in-between phenomenon, however, is not only a matter of how the countries formulate their alliances but also how it affects domestic politics and profound societal choices. Incentives to collaborate came from common concerns over security, economic necessity and societal development.

\section{Power of Historical Experience}

By exploring subregional formations over the longue durée, what emerges is a highly interesting pattern where two trends run parallel most of the time. On the one hand,

\footnotetext{
${ }^{6}$ Jenö Szûcs, Vázlat Európa három regiójáról (Budapest: Magvetö, 1983); Balázs Trencsényi, 'Central Europe', in Diana Mishkova and B. Trencsényi (eds.), European Regions and Boundaries: A Conceptula History (New York and Oxford: Berghan Books, 2017).

7 József Benedek, 'Régiók kialakulása és változása', Tér és társadalom 24, no. 3 (2010): 193-201.
} 
ideational deliberations sketched long-term development but these schemes never materialised. The realised integrative constructions, on the other hand, were pragmatic reactions to changes on the international arena. In both trends, three types of integration emerged: alliance, federative design, and development model. Alliances were immediate reactions to dramatic changes in the security environment and aspired to establish institutional structures, with formal and informal modus operandi. Federations represented a deeper level of cooperation, which evolved towards centralisation with one state in a leading position. It is seldom remembered, for example, that Austria in the $16^{\text {th }}$ century originally offered a federative context for small nations seeking shelter from the Ottoman invasion. By the $17^{\text {th }}$ century this federation transformed into the Habsburg Empire. Perhaps the most intensive and lasting integrative model occurred when collaboration was based on a shared idea of development. This type of ideational bond between the countries created a symbiotic collaboration that made institutional structures less important in steering or timing cooperation. There were also less incentive for the individual states to seek a central role. While alliances and federations relied on normative-formal settings, the common platform of development leaned on a more authentic association.

Common interest towards subregionality emerged already in the Middle Ages. In 1335, the Polish King Casimir the Great, the Bohemian (Czech) King John Luxemburg and the Hungarian King Carl Robert met in the Hungarian royal palace, located at the time in Visegrád, to create a customs union to stand up against Austria's staple rights that harmed these kingdoms' Western trade. While this alliance was short-lived, it created an area specific model to seek security via cooperation against the changing geopolitical realities. The age of nationalism in the $19^{\text {th }}$ century launched a renewed enthusiasm for small nations to fight against the imperial context. The federalisation of the Habsburg Empire, and its successor, Austro-Hungarian Dual monarchy (18671918), was widely perceived as viable a framework. Hungarians such as Lajos Kossuth and Oszkár Jászi, Czechs like Thomas Garrigue Masaryk and Edvard Benes, and Ignacy Jan Paderewsky from Poland, all proposed a New Central Europe. ${ }^{8}$ This idea

\footnotetext{
${ }^{8}$ Lajos Kossuth, 'A Dunai Szövetség tervezete', Magyar Elektronikus Könyvtár, 1 May 1862, available at http://mek.niif.hu/04800/04882/html/szabadku0178.html (accessed 30 October 2019); Oszkár Jászi, 'Magyarország jövöje és a dunai egyesült államok' (Budapest 1918), Magyar
} 
simultaneously challenged Eastern autocracy, Western imperialism and both Eastern and Western Marxism, since these ideologies denied the paradigm of the nation-state.

The First World War modified the international environment dramatically, and the disintegration of great empires gave way to new sovereign states in East Central Europe. ${ }^{9}$ The knowledge of being situated in a buffer zone between the Western powers and Soviet Russia had an impact on their conceptions of security. These new countries had to adjust national interest within the radically changed international context - defined by the war-winning powers who tended to favour collective security. ${ }^{10}$ Great powers were eager to offer various scenarios for subregional integration as a means of competing over the area. One such alliance was proposed by France seeking to increase influence in the region, which in the previous decades had been a target of both pan-Slavism (driven by Russia) and pan-Germanism. France put pressure on Yugoslavia, Czechoslovakia and Romania to form the 'Little Entente', as a security alliance designed to prevent territorial revisions by war-losers Hungary and Bulgaria. The Little Entente would also provide a framework also for economic cooperation. French policy aimed to polarise Central Europe but the countries did not adapt to its vision of friends and foes. France needed Poland to create a strong Cordon Sanitaire (or buffer zone) against Soviet Russia but the French initiative failed to take into consideration that, for Poland, historical symbolic-informal relations bore more weight than formal-institutional advantages. Poland had territorial disputes with the Czechs but traditionally cordial relations with the Hungarians. ${ }^{11}$ Future President of Czechoslovakia, Edvard Beneš, in turn suggested a compromise, transforming the

Elektronikus Könyvtár, available at http://mek.oszk.hu/09300/09364/09364.pdf (accessed 30 October 2019); Thomas G. Masaryk, The Problem of Small Nations in the European Crisis (London: The Council of for the Study of International Relations, 1916); Thomas G. Masaryk, The New Europe. The Slav Standpoint (Lewisburg: Bucknell University Press, 1972); Eduard Benes and Jaroslav Paponsek, Gedanke und Tat: aus den Schriften und Reden (Frankfurt am Main: Ullstein, 1976); Eduard Benes, First Exposé in Year of Work (1919), 9-38. Hanna Marczewska-Zagdanska and Janina Dorosz, 'Wilson - Paderewski - Masaryk: Their Visions of Independence and Conceptions of How to Organize Europe', Acta Poloniae Historica 73 (1996): 55-69.

9 Janos C. Andrew, East Central Europe in the Modern World. The Politics of the Borderlands from Pre- to Postcommunism (Stanford: Stanford University Press, 2000), 411.

${ }^{10}$ Ibid., 100.

${ }^{11}$ Piotr Wandycz, 'The Little Entente: Sixty Years Later', The Slavonic and East European Review 59, no. 4 (1981): 548-64. 
Little Entente into a Central European league which included Poland, Bulgaria, Greece, the Baltic countries and Ukraine. The aim was to create a wider belt against Soviet Russia and Austrian, German and Hungarian revisionists. ${ }^{12}$

French influence faded away by mid-1930s, even though it made efforts to develop the Little Entente institutionally by establishing a permanent secretariat in 1932. ${ }^{13}$ With Germany rising in the west and Stalinist Russia strengthening in the east, in-between-ness became an increasingly topical question in East Central Europe to address the context of the times. Poland came up with a wide-ranging strategic concept - the Intermarium idea - which envisaged a broad coalition of Eastern European states reaching from Finland in the north to Greece in the south and with Poland at its centre. The coalition was supposed to strengthen the cumulative military capacity and geopolitical weight of small countries caught between the politically turbulent Soviet Union and the West. ${ }^{14}$

Another scenario was initiated by Italy in 1937. The Third Europe concept included Poland, Hungary, Romania, Yugoslavia and Italy - with double centres of Hungary and Poland - resulting in common border dividing the territory of Czechoslovakia. ${ }^{15}$ On the eve of the Nazi Anschluss the following March, it was obvious that Hitler would turn on Czechoslovakia - hence German influence had to be countered. This 'horizontal axis', as the Italian Minister of Foreign Affairs, Galeazzo Ciano called it, would contain both German and Soviet expansion to East Central

\footnotetext{
${ }^{12}$ Eduard Benes, 'The Little Entente', Foreign Affairs 1, no. 1 (1922): 66-72.

${ }^{13}$ Pál Dunay, 'Subregional Cooperation in East Central Europe: the Visegrád Group and the Central European Free Trade Agreement', Österreichische Zeitschrift für Politikwissenschaft 32, no. 1 (2003): 45-56, here 45.

${ }^{14}$ Piotr Cieplucha, 'Prometeizm i koncepcja Międzymorza w praktyce polityczno-prawnej oraz dyplomacji II RP', Studia Prawno-ekonomiczne 93 (2014): 39-55; Robert Istok, Irina Kozarova and Anna Polackova, 'The Intermarium as a Polish Geopolitical Concept in History and in the Present', Geopolitics (published online 6 December 2018)

https://www.tandfonline.com/doi/full/10.1080/14650045.2018.1551206 (accessed 30 October 2019).

${ }^{15}$ Magda Ádám (ed.), Volume 2: A Müncheni szerzôdés létrejötte, document no. 17, in László Zsigmond (ed.), Diplomáciai iratok Magyarország külpolitikájához, 1936- 1945 (Budapest: Akadémiai Kiadó, 1962-1982).
} 
Europe. ${ }^{16}$ Third Europe would further help Italy to strengthen its positions in the Berlin-Rome axis vis-à-vis Germany. ${ }^{17}$

Interestingly, the drive for subregional integration during the interwar period took place at a time when the majority of these countries had just achieved independence. Yet, there appeared a seemingly mutual understanding that cooperation was inevitable for protecting sovereignty. Nevertheless, while there were numerous great power initiatives aiming to create and control sub-regional alliances, the ECE countries modified these scenarios for their own purposes. After the Second World War, the governing incentive for collaboration was to ensure economic prosperity and societal development, in contrast to the security-driven aims of the interwar years.

The Cold War juxtaposition further revised the notion of regionality: the countries of East Central Europe were cut off from their Western counterparts and the communist order pushed the countries to a new orbit of development. Subregional collaboration was reorganised institutionally by the Moscow-led Eastern bloc ally system, which emphasised a centre-periphery structure in the beginning. The most important frameworks of formal cooperation were the multidimensional network of Friendship and Mutual Assistance Treaties, the Council for Mutual Economic Assistance (CMEA) economic alliance and the security organisation of the Warsaw Pact. Since the 'satellites' were unable to change their geopolitical situation, they gradually developed survival strategies to come to terms with the status quo. A new opportunity opened up when the Stalinist development model, based on heavy industry and extensive economic growth, reached its dead end. ${ }^{18}$ Reform communism was a typical in-between invention of Czechoslovakia, Hungary and Poland that relied

\footnotetext{
${ }^{16}$ Minutes of conversation between Prince Paul and Ciano, Mar. 25, 1937. Cited in J. B. Hoptner, Yugoslavia in Crisis, 1934-1941 (New York: Columbia University Press, 1962), 83. Also Malcolm Muggeridge, ed., Ciano's Diary, 1937-1938, entry March 9, 1938 (London: Dutton, 1952).

${ }^{17}$ Lajos Kerekes (ed.), Volume 1: A Berlin-Roma tengely kialakulása és Ausztria annexiója, 19361938, documents no. 354, 357; Magda Ádám (ed.), Volume 2: A Müncheni szerzôdés létrejötte, documents no. 123, 115, 382, both in László Zsigmond (ed.), Diplomáciai iratok Magyarország külpolitikájához, 1936- 1945 (Budapest: Akadémiai Kiadó, 1962-1982). Jozef Beck, Final Report (New York: R. Speller, 1957), 143.

${ }^{18}$ Extensive growth is an economic model where the increase of industrial production is based on the quantitative extension of input of raw materials, energy and human workload.
} 
on a market socialist model, blending Western elements with the Eastern system. It opened up the possibility for entrepreneurship, small scale private property, consumption-led industry and more liberal social atmosphere. ${ }^{19}$ This in-between development strengthened further in the 1970s due to the Helsinki process, which by emphasising multilateralism after decades of superpower-led polarisation - helped the ECE countries to re-establish direct contacts with the West. ${ }^{20}$ This pragmatic attitude towards Western opportunities, lacking nearly all Marxist-Leninist ideological inclinations, bore a consequence on the reformers' relations with the Kremlin. While the ECE states were unable to establish an independent coalition, they nevertheless allied unofficially to protect Western trade against the Russian aims of deepening CMEA integration. ${ }^{21}$

Increasing interactions with the West stimulated dissidents' discussions about the concept Third Europe as a development scenario. Prominent figures drawn from the Polish, Czech and Hungarian intelligentsia argued that the East Central Europeans were plain objects of history and simple pawns in the superpowers' game, and that this shared experience had a devastating effect on people's identity. The way out from this stalemate, it appeared, would be for geopolitical in-between-ness to grow into a new in-between political option, challenging both capitalism and state socialism. Third Europe would rely on civil society as the ultimate source of political power. ${ }^{22}$

The historical examples discussed above show that the different integrative models overlapped and even evolved from one another, indicating that numerous

\footnotetext{
${ }^{19}$ Katalin Miklóssy, 'Khrushchevism after Khrushchev: The Rise of National Interest in the Eastern Bloc', in Jeremy Smith and Melanie Ilic (eds), Khrushchev in the Kremlin: Policy and Government in the Soviet Union, 1953-1964 (London and New York: Routledge, 2010), 150-170.

${ }^{20}$ Katalin Miklóssy, 'The Helsinki Process and the Finnish Model from Small States' Perspective: Hungarian and Romanian CSCE-Strategies in Comparison', in Anders Blomqvist, Constantin Iordachi and Balázs Trencsényi (eds), Comparisons and Entanglements: Hungary and Romania beyond National Narratives (New York and London: Peter Lang, 2013), 485-514.

${ }^{21}$ Suvi Kansikas, Socialist Countries Face the European Community: Soviet Bloc Controversies over East-West Trade (New York - London: Peter Lang, 2014), also Kansikas, 'Room to manouvre? National interests and coalition building in the CMEA, 1969-1974', in Sari Autio-Sarasmo and Katalin Miklóssy (eds), Reassessing Cold War Europe (London and New York: Routledge, 2011), 193-209.

${ }^{22}$ The idea was developed by dissident intellectuals Vaclav Havel in his Power of the Powerless (1978), György Konrád in his Antipolitics (1984), Milan Kundera in The Tragedy of Central Europe (1984) and Adam Michnik in his Letters from the Dansk Prison (1985).
} 
alternatives were seen as available in any one period of time. Some of these plans remained unrealised while some were carried out, giving way again to new ideas for reinventing subregional collaborations in an indefinite cycle. The historical experience of enduring alliances indicated that the common stand helped to keep at bay the nearby great powers' urge to extend influences over the territory. The image of a concerted group lent more weight to the international arena and expanded the individual countries' elbowroom. Locating themselves between East and West provided manoeuvring potential.

\section{The Role of Parallel Subregional Organisations in European Integration}

The dramatical change in the international power equilibrium following the end of the Cold War influenced the political and economic choices of the ECE countries. Amid the nascent post-1989 environment, the common dilemmas of democratization and marketization intensified the push towards subregional cooperation. The main question confronting decision-makers was how to make the fastest transition from the Soviet-centred framework towards Western institutions. Collective action was deemed essential to helping further the prospects of EU membership because, as was widely perceived at the time, many in Western Europe were not overtly keen to start enlargement negotiations with the former Eastern bloc members. Only a few years prior to the fall of the Berlin Wall the then European Community (EC) had still supported the erosion of the Soviet system. And while diplomatic relations between the Community and the communist bloc had been put on a more constructive footing by June 1988 the subsequent collapse of the communist regimes still took the EC by surprise. Hence, the first discussions with the East Central European countries tended to centre on creating partnership agreements rather than opening up membership negotiations. Delaying accession therefore became a central tactic of the EC/EU over the coming decade, even if the stability of the region was considered vital. Attention was instead paid to ensuring that the large ECE market could become an economically reliable partner with which to trade; this in turn required a predictable, stable local 
political context. ${ }^{23}$ Consequently, the EU established new instruments to confine these countries, most notably the Pologne-Hongrois Action pour la Reconstruction Economic (PHARE) programme, which was signed with Poland and Hungary in January 1990, and which in December 1991 led to a Partnership Agreement - a sort of two-step process later extended to other transitioning countries. ${ }^{24}$

Despite being deferred in short-term, the EU membership nevertheless gave succour to democratisers in the East. It was the prospect of joining the EU, combined with the sense of needing to accelerate this accession process, which gave freh relevance to the Visegrad union, this time institutionalised in the form of the Visegrad Group or, more commonly, the V4. Its founding declaration was signed on 15 February 1991 by prominent figures from the region, including Vaclav Havel (Czech and Slovak Republic), Lech Walesa (Poland) and József Antall (Hungary). As each of them made clear, the priorities of collaboration were to secure independence and assist in democratisation. ${ }^{25}$ While the largest portion of the declaration was concerned with the internal development of the $\mathrm{V} 4$, however, it became obvious that achieving the EU membership was the prime engine of collaboration. Interestingly, there was no reference to economic relations although the idea of a customs union emerged in the meeting.

To this end, the former Eastern bloc countries would need a new solution for a common market to replace the CMEA, which was officially dissolved a few month later in June 1991. By December 1992, the Central European Free Trade Agreement (CEFTA)

\footnotetext{
${ }^{23}$ Agence Europe, Europe Daily Bulletin no. 4957, 17 February 1989, Historical Archives of the European Union, available at https://archives.eui.eu/en/fonds/444512?item=AGE-557 (accessed 30 March 2019); David Buchan, 'EC Moves to Co-ordinate Policy on Eastern Europe', Financial Times 25 April 1989. Karen E. Smith, The Making of EU Foreign Policy: The Case of Eastern Europe (Basingstoke and New York: Palgrave Macmillan, 2004), 43-65.

${ }^{24}$ Council of the European Union, 'Council Regulation (EEC) No 3906/89 of 18 December 1989 on economic aid to certain countries of Central and Eastern Europe', Publications Office of the EU, available at https://publications.europa.eu/en/publication-detail/-/publication/2f1d2bc5-98984b73-b9dd-52efaaba3bde/language-en/format-PDF/source-search (accessed 30 October 2019). ${ }^{25}$ Visegrád Group, 'Visegrad Declaration 1991: Declaration on Cooperation between the Czech and Slovak Federal Republic, the Republic of Poland and the Republic of Hungary in Striving for European Integration', available at http://www.visegradgroup.eu/documents/visegraddeclarations/visegrad-declaration-110412 (accessed 30 March 2019).
} 
had therefore been established, with multiple purposes. ${ }^{26}$ In addition to creating a free trade zone among themselves, CEFTA would help to improve competitiveness visà-vis Western Europe and demonstrate the ability of the ECE countries to cooperate. Hence, the initials CEFTA purposefully resembled those of the European Free Trade Association (EFTA), which had promoted economic integration with non-Community Western European countries since the 1960s. In so doing, CEFTA sought to become the 'Benelux of the East'. ${ }^{27}$ An equally important aim of CEFTA was to liberalise trade within the ECE region. This is why CEFTA was originally linked exclusively to the Visegrád Group and was founded on strict accession rules. In 1995, for example, the countries had to change CEFTA's founding agreement in order to include Slovenia, which was then approaching the level of economic development as already seen by the V4. Later Romania and Bulgaria joined. CEFTA would also help to increase intraregional trade, despite the fact that after the EU's Copenhagen summit in June 1993 (more on which below) the attention of the ECE states focused almost exclusively on building economic relations with the EU as a main partner. ${ }^{28}$ In the 2000 s, moreover, it became obvious that the CEFTA was a typical transition-arrangement: in a July 2003 meeting held in Bled on the eve of their accession to the EU, the members decided that CEFTA would automatically cease upon EU membership. ${ }^{29}$ Since CEFTA and free trade matters were separated institutionally from the $\mathrm{V} 4$ and functioned as a parallel organisation, Visegrád could focus on other topics of cooperation and thus continue to exist long after CEFTA had served its purpose.

The above-mentioned Copenhagen summit transformed the inner dynamics of the ECE countries because, for the first time, EU leaders declared that the Visegrád Group could well become full members in the Union with corresponding access to the single market. This was soon followed by the association agreements signed during

\footnotetext{
${ }^{26}$ Central European Trade Agreement - Founding Document, 21 December 1992, available at https://web.archive.org/web/20070614090538/http://www.worldtradelaw.net/fta/agreements/ cefta.pdf (accessed 30 March 2019)

${ }^{27}$ Andrzej Rudka and Kálmán Mizsei, 'The Fall of Trade in East Central Europe: Is CEFTA the right solution?' Russian \& East European Finance and Trade 30, no. 1 (1994): 6-31, here 18.

${ }^{28}$ Ibid., 6-31.

${ }^{29}$ Lajos Arday, 'Közép-Európa és a Visegrádi Négyek', International Relations Quarterly 6, no. 1 (2015): 1-5.
} 
the course of 1993 and 1994. The EU, however, did not give any specific date for starting concrete negotiations until 1997. This delay tactic was a game-changer for the Visegrád alliance, the culmination of which threw into question its political worth. For one, the V4 did not need group-effort anymore to improve visibility in the West. Moreover, cooperation relied on the willingness to compromise, which the deteriorating personal relations of leading figures made increasingly difficult. And the diverging orientation of the V4 was a clear sign that the countries were beginning to lose faith in the idea that V4 alliance would accelerate accession. The velvet divorce of the Czech Republic and Slovakia in 1993 put these countries into a further difficult position, which Poland and Hungary utilized to speed up their own accession procedures with the EU. Thus emerged a degree of competition over which country could possibly secure EU membership first. The Czech Prime Minister, Vaclav Klaus, stated that since his country was more advanced than the rest, it was able to join the EU any time by itself. Cordial relations with Germany were more important for the Czech Republic than the Visegrád Group. ${ }^{30}$ At about the same time, Poland started having problems with political instability and its attention turned from regional to domestic matters. ${ }^{31}$ Meanwhile, due to growing tensions with Hungary over minority issues, the Slovakian nationalist Prime Minister, Vladimir Meciar, oriented towards the Russian Federation, and away from regional collaboration. For their part, the Hungarians focused on the Balkans and simultaneously sought to improve their relations with Austria and Italy, both of which were members of the CEI.

The CEI, a parallel institution to the Visegrád alliance and CEFTA, was originally a multilateral collaboration founded in November 1989 by Austria, Italy, Hungary and Yugoslavia. ${ }^{32}$ This foursome soon enlarged to include Czechoslovakia (1990) and Poland (1991), while Yugoslavia was suspended because of the ensuing succession wars. In the early 1990s, it was not yet evident that the CEI would struggle to develop

\footnotetext{
30 Vaclav Klaus, 'The Czech Republic and European Integration', Perspectives, no. 2 (1994): 7-11. Also Milos Gregor and Alena Mackova, 'Euroskpeticism the Czech Way: Analysis of Vaclav Klaus' Speeches', European Journal of Communication 30, no. 4 (2015): 404-17.

${ }^{31}$ Between 1992 and 1998 there were six consecutive administrations.

${ }^{32}$ Central European Initiative, 'Central European Initiative 1989-2009 Years', available at https://www.cei.int/sites/default/files/publications/downloads/booklet\%20final\%20low.pdf
} (accessed 30 March 2019). 
into a more efficient organisation. Thus, it was a safety option should the V4 alliance have failed to meet expectations. The CEI resembled the interwar 'horizontal axis' idea and Italian aims to increase a presence in the Central European sphere to counterbalance Germany's traditional interest. Austria, on the other hand, saw an opportunity to retrieve influence on what once was the Habsburg Empire. Along with these aspirations, Austria oriented towards the Visegrád Group but the V4 disagreed about whether to allow Austria to become a member. By 1996, the CEI expanded to include a further 17 countries - including the new post-Yugoslav countries, Albania, Bulgaria, Romania, Belarus, Ukraine and Moldova. The CEI was a loose alliance with the task of easing the way towards Western institutions. Yet it could never agree upon any common political programme or institutional infrastructure. Rather, it remained a forum of exchanging ideas about current political and economic problems. By 1997, the CEI was largely redundant from the East Central European perspective, partly because of the expansion towards areas that were not considered as benchmark countries for the V4. ${ }^{33}$ The CEI was also taken over by the EU in the following decade and turned into an instrument to deal with Eastern Partnership countries and EU candidate countries. Its purpose changed to strengthen democratisation in the Eastern neighbourhood by channelling funds and organising governmental meetings. ${ }^{34}$ Like the CEI, CEFTA was also losing significance as EU accession moved closer. And because of the improving prospect of EU entry, the V4 once again began to invest in the Visegrád alliance.

This renewed appeal of Visegrad cooperation emerged towards the close of 1998. ${ }^{35}$ Beyond the immediate prospect of joining the EU, several other factors helped ease V4 rapprochement. Personal changes were one: Klaus and Meciar had left office, and their successors put more weight on subregional cooperation. ${ }^{36}$ The Czech

\footnotetext{
${ }^{33}$ Dunay, 'Subregional', 47.

${ }^{34}$ See the official website CEI: Central European Initiative 30 years, available at https://www.cei.int/ (accessed 14 October 2019) also CEI, 'CEI Plan of Action, 2018-2020', CEI website, available at https://www.cei.int/sites/default/files/file/PoA\%2020182020\%20FINAL\%20web\%20(006).pdf (accessed 22 January 2020).

${ }^{35}$ Károly Gruber, 'In Search of Better Coordination and Representation of Shared Interests: Visegrád cooperation within the European Union', Foreign Policy Review, no. 7 (2010): 37-53. ${ }^{36}$ The nationalists Vaclav Klaus and Vladimir Meciar were replaced by the liberal Milos Zeman and Mikulas Zurinda.
} 
economic leap had worn out too, questioning the viability of entering the EU alone. And the need to once again work together within the confines of the V4 seemed all the more important because in March 1999 the East Central European countries were set to join the North Atlantic Treaty Organization (NATO). Seen in this light, Visegrád had the potential increasingly to turn into a security community. The Visegrad alliance thus met in October in Budapest and declared it was time to restart collaboration. Just over a year later, at a meeting in Bratislava, the countries also agreed that new content and ways of working were required to intensify their relations. ${ }^{37}$ Cooperation subsequently extended not only to security and the willingness to establish joint military-industrial production sectors but also to day-to-day issues such as traffic, communication, environment, and cultural and educational affairs. The new International Visegrád Fund would in turn help with exchanging ideas and integrating officials in the region. ${ }^{38}$ While this initiative resembled the EU's principles of interaction and mobility, it nevertheless openly challenged the EU as it aimed to strengthen a subregional identity instead of an all-European one.

\section{'Divide et impera': EU's stand on the V4}

Amid this context, the EU grew increasingly suspicious of the Visegrad's subregional alliance. The Budapest and Bratislava meetings had both seen the revival of the idea that the V4 shared common interest, and this was likely to have a profound impact on the way in which they the EU as accession talks finally got underway. The EU was itself well aware that through concerted action the Visegrád countries might try to negotiate more favourable terms of entry. Despite its Copenhagen declaration having stated a desire to deal with the Visegrád Group 'en bloc', it thus now decided to keep the process strictly bilateral. This was confirmed by the European Commission's

\footnotetext{
${ }^{37}$ Visegrád Group, 'Contents of Visegrád Cooperation 1999: Contents of Visegrad Cooperation approved by the Prime Ministers' Summit, Bratislava on 14th May 1999', available at http://www.visegradgroup.eu/cooperation/contents-of-visegrad-110412 (accessed 30 March 2019).

${ }^{38}$ Visegrád Group, 'International Visegrad Fund', available at http://www.visegradgroup.eu/visegrad-fund/international-visegrad (accessed 30 March 2019)
} 
publication Agenda 2000 about the strategy of enlargement after the Luxemburg summit in $1997 .^{39}$

In the meantime, the Visegrád countries' prime ministers met regularly between 1998 and 1999. ${ }^{40}$ They were anxious to get the EU to announce the timetable for accession, which it finally did in March 1999 by proclaiming 2004 as the year of integration. The EU's Enlargement Commissioner, Günter Verheugen, later presented a roadmap. ${ }^{41}$ Keeping the budget negotiations strictly on a bilateral basis and behind closed doors was an efficient tactic to play the V4 against each other. The common stand that had started to build in Budapest and Bratislava hence ended abruptly because EU support for the accession countries was understood as a zero-sum game, and each prime minister tried to squeeze out as much development aid as possible for their own country. The negotiation strategy of the EU, however, bore a counterproductive consequence: while it indeed helped to downplay the common subregional stand, it also strengthened the national and even nationalist agenda.

Before the accession, old and new 'Europe' clashed, which was a warning sign for the future unity of the EU. NATO membership increased the influence of the United States in Central Europe, and the V4 did not hesitate to show loyalty in 2003 by participating in the US mission in Iraq, irrespective of the fact that France and Germany refused to do so. The US State Secretary Donald Rumsfeld proclaimed the new NATO allies as 'new Europe' and claimed that the focal point of political power on the continent appeared to be moving from West to East. ${ }^{42}$ The French President, Jacques Chirac, became annoyed by Rumsfeld's mockery and offended new EU candidates as

\footnotetext{
${ }^{39}$ European Commission, 'Agenda 2000: For a Stronger and Wider Union', Bulletin of the European Union Supplement 5/97, available at https://ec.europa.eu/agriculture/sites/agriculture/files/cap-history/agenda-2000/com972000 en.pdf (accessed 30 March 2019)

${ }^{40}$ The prime ministers of the V4 met three times within one year: 21 October 1998, 14 May 1999 and 15-16 October 1999.

${ }^{41}$ Wilfried Loth, Building Europe: A History of European Unification (Berlin: De Gruyter, 2015), 372-74.

42 Donald Rumsfeld, 'Briefs at the Foreign Press Center' 23 January 2003. https://www.youtube.com/watch?v=E0GnRJEPXn4
} 
'infantile'. He stated bluntly that newcomers 'missed a good opportunity to keep quiet' - which, unsurprisingly, poisoned the atmosphere still further. ${ }^{43}$

French insults had another unintended impact on events. From the point of view of EU unity, the Visegrád countries decided to modernise their collaboration patterns, hoping to strengthen their common ground and better represent their interests within the EU. In May 2004, the V4 prime ministers met and stated that while accession to NATO and the EU were "historic milestones", strengthening a regional or "Central European identity" was equally important. ${ }^{44}$ The streamlining of activities was, however, not regarded favourably in the EU. Chirac's successor, Nicholas Sarkozy, warned the Visegrád countries that regular V4 meetings before EU summits were undesirable and "could raise questions" - ignoring of course that the French and German leaders also met regularly before EU summits. ${ }^{45}$ Yet another French president - Emmanuel Macron - made an attempt to undermine Visegrád unity, on the related matters of migrant workers in France and EU migration policy. On 23 August 2017, as a sign of his annoyance, Macron travelled to Salzburg to meet Czech Prime Minister Bohuslav Sobotka and his Slovak counterpart, Robert Fico, while leaving Poland and Hungary out. And when doing so he promised the Czechs tolerance with migrant quotas and, for the Slovaks, the opportunity to integrate them into the centre of EU

\footnotetext{
${ }^{43}$ President Chirac presented his accusations on the candidate countries in a press conference on Iraq in Brussels 17 February 2003, see for example The Guardian, 18 February 2003. The Polish Minister of Foreign Affairs, Cimoszewicz and the Czech MEP Vladimir Lavtuska reacted immediately. See James Graff, 'Europe's Family Feud', Time Magazine 14 February 2003; Mart Laar, 'New Europe won't keep quiet until Europe is new', Wall Street Journal Europe, 19 February 2003; Judy Dempsey, 'Summit outcome leaves future members reeling', Financial Times, 19 February 2003.

${ }^{44}$ Visegrád Group, 'Visegrad Declaration 2004: Declaration of Prime Ministers of the Czech Republic, the Republic of Hungary, the Republic of Poland and the Slovak Republic on cooperation of the Visegrad Group after their accession to the European Union (12 May 2004)', available at http://www.visegradgroup.eu/documents/visegrad-declarations/visegraddeclaration-110412-1 (accessed 30 October 2019)

${ }^{45}$ Honor Mahony, 'Sarközy warns Visegrad countries not to make a habit of pre-summit meetings', EUobserver (4 November 2009). https://webcache.googleusercontent.com/search?q=cache:D8Mc14IVwsJ:https://euobserver.com/news/28928+\&cd=1\&hl=en\&ct=clnk\&gl=hu\&client=firefoxb-d
} 
decision-making. Neither 'sticks', mentioned above, nor this 'carrot' policy worked in breaking up the V4. There was, after all, much more at stake.

\section{Streamlining Cooperation within the EU}

The original Visegrád alliance had as its goals the furthering of democratisation, economic development, and speeding up accession to the EU. These aims were achieved in 2004 but the alliance was still needed. A new strategy was established to defend V4 interests in two ways: on the one hand, it was deemed paramount to come up with constructive ideas in developing EU policy. On the other hand, it was equally important to become an equal member of the EU because, from the newcomers' point of view, it was an upstairs-downstairs type of double-standard community. Soon after accession in May 2004, V4 prime ministers consequently defined as a new priority their active involvement in shaping further enlargement of the EU towards the east and south-east of the continent. ${ }^{46}$ It was clear that the V4 needed their own buffer zone in an area that was struck by decades of Yugoslavian war, violent nationalism, and an unpredictable Russia - all of which was in their vicinity. In the 2005 Budapest summit, the V4 launched Regional Partnership combining also Austria and Slovenia. The target of the partnership was stability and security in the Western Balkans. The Czech EU presidency in 2009 provided an opportunity to drive subregional aims in this respect. As Marek Neuman has pointed out, this was also a testing ground of what could be achieved by the Czechs with group-power behind them. ${ }^{47}$ Since the Czech Republic held the rotating presidency of the Visegrád Group between June 2007 to June 2008 , its leadership consulted the V4 to formulate its intended agenda for the EU

\footnotetext{
${ }^{46}$ Visegrád Group, 'Visegrad Declaration 2004: Declaration of Prime Ministers of the Czech Republic, the Republic of Hungary, the Republic of Poland and the Slovak Republic on cooperation of the Visegrad Group after their accession to the European Union (12 May 2004)', available at http://www.visegradgroup.eu/documents/visegrad-declarations/visegraddeclaration-110412-1 (accessed 30 October 2019)

${ }^{47}$ Marek Neuman, 'The Visegrad Group as a Vechile for Promoting National Interest in the European Union: The Case of the Czech Republic', Politics in Central Europe 13, no. 1 (2015): 5567.
} 
presidency and get support on the EU level. The Czechs aimed to 'streamline' Visegrád cooperation, especially in relation to security in the wider regional context. ${ }^{48}$

Within this environment, Poland became particularly active. Warsaw was for instance instrumental in designing a detailed policy agenda, the Eastern Partnership, which was an attempt to hinder Russian influence in the post-Soviet republics and create a buffer belt of sovereign states between Poland and Russia, realised with the help of the EU. ${ }^{49}$ The Eastern Partnership policy initiative was accepted by all V4 members and in the process established a new way of working within the EU. ${ }^{50}$ This was a good example of how to upload subregionally important issues onto the EU decision-making agenda through joint action. The Eastern Partnership programme became a broadly supported EU policy, launched officially at the Prague summit in May 2009. The buffer-belt idea was closely related to the need to rethink security matters from subregional perspectives. The formation of the Visegrád Battle Group was raised already in 2009/10, but later in 2013 it was presented as the V4 contribution to EU defence policy and in 2014 it was offered as a contribution to NATO. ${ }^{51}$

\footnotetext{
${ }^{48}$ Visegrád Group, 'Czech Presidency of the Visegrad Group (June 2007-June 2008)', available at http://www.visegradgroup.eu/documents/presidency-programs/2007-2008-czech-110412 (accessed 30 October 2019)

${ }^{49}$ Katalin Miklóssy and Justyna Pierzynska, 'Regional strategic culture in the Visegrad-countries: Poland and Hungary', in Katalin Miklóss and Hanna Smith (eds), Strategic Culture in Russia's Neighbourhood: Change and Continuity in an In-Between Space (Lanham MD: Lexington, 2019). ${ }^{50}$ Visegrád Group, 'Joint Statement of the Ministers of Foreign Affairs of the Visegrad Group Countries and of Bulgaria, Estonia, Lithuania, Latvia, Romania and Sweden', (24 November 2008), available at http://www.visegradgroup.eu/2008/joint-statement-of-the-110412-4 (accessed 30 October 2019)

${ }^{51}$ Ivo Samson, 'Assessment of Visegrad cooperation from a security perspective: Is the Visegrad Group Still Vital in the "Zeros" of the 21st century?', in Csaba Törö (ed.), Visegrad cooperation within NATO and CSDP (Warsaw: Polish Institute of International Affairs, V4 Papers, no. 2, 2011), 9-40. See also Visegrád Group, 'Annual Report 2009/2010 of the Hungarian V4 Presidency', available at http://www.visegradgroup.eu/documents/annual-reports/2009-2010-hungarian110412 (accessed 30 October 2019); Piotr Bajda (ed.), 'Report of the Polish Presidency of the Visegrad Group, July 2012-June 2013', (Warsaw: Ministerstwo Spraw Zagranicznych Rzeczpospolitej Polskiej, 2013), available at http://www.visegradgroup.eu/documents/annualreports (accessed 30 October 2019); Visegrád Group, 'Report the Hungarian Presidency of the Visegrád Group, July 2013 - June 2014', available at http://www.visegradgroup.eu/documents/annual-reports/report-hu-v4-pres-07 (accessed 30 October 2019) .
} 
In addition to security matters, the economic realities of EU membership helped to intensity of V4 cooperation. As new comers, they realised that the EU's single market was to open up only gradually and that mobility of their citizens would be restricted. ${ }^{52}$ Being 'second class members' obliged the V4 to develop a common strategy to pressure the EU to improve access to the Schengen area. ${ }^{53}$ The cohesion of the V4 grew gradually stronger in subsequent years, alongside the rise of their EU criticism. ${ }^{54}$ The first signs of dissatisfaction with the EU became evident in the European Parliament elections in 2009 and 2014, which saw considerable success for EU-sceptic parties in the region. ${ }^{55}$ In 2013, during the Polish Visegrád presidency, the V4 stressed that subregional cooperation was in fact the cornerstone of the European Union's policymaking framework and they intended to strengthen their cooperation. ${ }^{56}$ The Slovak Visegrád presidency in 2015 went further and underlined the importance of coordinating common positions in European affairs, under the motto 'Dynamic Visegrád for Europe and Beyond'. ${ }^{57}$

Growing criticism of the EU, articulated in these Visegrád documents, can also be seen in the revival of different scenarios for increasing subregional unity. The recycled in-between concepts re-emerged in new forms. The Three Seas Initiative (Trimarium), promoted by the Polish President Jerzy Duda in 2015, evoked the interwar Intermarium concept, although it has been argued that it was an

\footnotetext{
${ }^{52}$ Schengen Visa Info, 'Schengen Agreement', available at https://www.schengenvisainfo.com/schengen-agreement/ (accessed 30 October 2019) ${ }^{53}$ Ivan T. Berend, Europe Since 1980 (Cambridge: Cambridge University Press, 2010), 42-96.

${ }^{54}$ See for example: Ministry of Foreign Affairs and Trade in Hungary, 'V4 Statement for the Future of Europe' (January 26, 2018), available at http://www.visegradgroup.eu/calendar/2018/v4-statement-on-the (accessed 22 January 2020); Martin Dangerfeld, 'V4: A new brand for Europe? Ten years of post-accession regional cooperation in Central Europe', Poznan University of Economics Review 14, no 4 (2014), 71-90. ${ }^{55}$ Parties and elections in Europe, European Election Database, available at www.parties-andelections.eu (Accessed 10 December 2017); See also Olga Gyárfášová, Mesežnikov, Grigorij (eds.), Visegrad elections 2010: domestic impact and European consequences. (Bratislava: Inštitút pre verejné otázky, 2011).

${ }^{56}$ Piotr Bajda (ed.), 'Report of the Polish Presidency of the Visegrad Group, July 2012-June 2013',

${ }^{57}$ Ministry of Foreign and European Affairs of the Slovak Republic, 'Report of the Slovak Presidency of the Visegrád Group, July 2014-June 2015', available at http://www.visegradgroup.eu/documents/annual-reports (accessed 28 October 2019).
} 
infrastructural and technological project aiming to modernise the EU's eastern flank. ${ }^{58}$ Trimarium delineates the geopolitical space between the Baltic, Black and Adriatic seas, and envisages cooperation among the Visegrád countries, the Baltic republics, Slovenia, Croatia, Bulgaria, Romania and Austria.

The affinity between the V4, and ensuing criticism of the EU, evolved most strongly however from the fact that similar national conservative political elites acquired power in these countries almost simultaneously. EU criticism also reflected an emerging new trend where the countries began to turn away from liberal democratic values. ${ }^{59}$ According to the annual reports of Freedom House on the state of democracy, it is obvious that EU membership did not strengthen democratic development in the Eastern European members. Between 2010 and 2020, the decline of democracy was noticeable in all Visegrád countries, especially in Hungary and Poland. ${ }^{60}$ According to Hungary's Prime Minister Viktor Orbán, the Visegrád Group represents an indigenous subregional development, which is more progressive than that of the Western countries because it is more open to other options. ${ }^{61}$ Orbán called for a strong Central European unity, basing its core on the solid alliance of Hungary and Poland. ${ }^{62}$ The migration crisis was a watershed moment in streamlining the

\footnotetext{
${ }^{58}$ Grzegorz Lewicki, 'The Three Seas Initiative Will Strengthen Europe', Visegrad Insight, available at http://visegradinsight.eu/the-three-seas-initiative-will-strengthen-europe/ (accessed 28 October 2019).

${ }^{59}$ Ladislav Cabada, 'Democracy in East-Central Europe: Consolidated, Semi-Consolidated, Hybrid, Illiberal or Other?', Politics in Central Europe 13, no. 2-3 (2017): 75-87. See also The Economist, 'Illiberal Europe. Big, bad Visegrad', The Economist 28 January 2016, available at http://www.economist.com/news/europe/21689629-migration-crisis-has-given-unsettling-newdirection-old-alliance-big-bad-visegrad (accessed 30 October 2019).

${ }^{60}$ Freedom House, 'Democracy in Retreat: Freedom in the World 2019', Freedom House website, available at https://freedomhouse.org/report/freedom-world/freedom-world-2019/democracyin-retreat (accessed 30 January 2020).

${ }^{61}$ Viktor Orbán, 'Speech', Website of the Hungarian Government 26 October 2017, available at http://www.kormany.hu/en/the-prime-minister/the-prime-minister-s-speeches/prime-ministerviktor-orban-s-speech-at-the-inauguration-of-bridgestone-s-new-plant (accessed 23 September 2019); also Viktor Orbán, 'Speech', Website of the Hungarian Government 21 June 2017, available at http://www.kormany.hu/hu/a-miniszterelnok/beszedek-publikaciok-interjuk/orbanviktor-beszede-a-visegradi-negyek-elnoksegenek-atvetelekor (accessed 23 September 2019). 62 V Post, 'Speeches of the Hungarian and Polish Prime Ministers on the Occasion of the Hungarian National Day, March 15 2019', Visegrad Post 16 March 2019, available at https://visegradpost.com/en/2019/03/16/speeches-of-the-hungarian-and-polish-prime-
} 
Visegrád Group's collaboration and common stand. Finding solutions to the migration problems overshadowed all other policy areas in the V4 meetings and in Visegrád-EU relations since 2015, since migration was perceived primarily as a security-related matter and a breach of sovereignty. In June 2018, the Visegrád Group even held a summit with Austria and declared their intention to set up a new mechanism to protect their borders on the Western Balkans. ${ }^{63}$ Finally, the different standing within the EU was once again demonstrated in May 2019 when EU-sceptics parties performed well in the European Parliament elections of that year and received a clear majority of all votes cast in the V4 states. ${ }^{64}$ The growing influence of the Visegrád Group became apparent during the nomination procedure of the new head of the European Commission when the entire Spitzenkandidat concept was torpedoed by the V4. ${ }^{65}$

The Visegrád alliance is an interesting phenomenon in itself. Institutional structures were kept intentionally weak because it was formed at a time when the goal of the EU membership was deemed more significant. Still, it has remained the most enduring collaboration pattern precisely because of its institutional flexibility. As an agile organisation devoid of complicated decision-making structures, it is to react relatively fast to changes in the international arena and, from time-to-time, open up to other regional actors in the vicinity like Austria, Italy, Slovenia, the Western Balkans

ministers-on-the-occasion-of-the-hungarian-holiday-of-march-15-full-speeches/ (accessed 23 September 2019).

${ }^{63}$ Visegrád group, 'Visegrád Group and Austria Summit Declaration on "Setting up a Mechanism for Assistance in Protecting the Borders of the Western Balkan Countries"', Visegrad Group Budapest 21 June 2018, available at http://www.visegradgroup.eu/visegrad-group-and (accessed 28 September 2019).

${ }^{64}$ European Parliament, '2019 European Elections Results: Constitutive Session 23/10/2019', European Parliament website, available at https://www.election-results.eu/ (accessed 28 October 2019).

${ }^{65}$ Visegrád Group, 'No sptizenkandidat should head EC - Czech PM Babis declares' (June 24, 2019), available at http://www.visegradgroup.eu/news/no-spitzenkandidat (accessed 30 October 2019; see also Agata Palickova, 'Visegrad leaders claim victory in race for EU jobs', Euroactive July 4, 2019 available at https://www.euractiv.com/section/eu-elections-2019/news/visegradleaders-claim-victory-in-race-for-eu-top-jobs/ (accessed 30 October 2019); see also Josef Janning, 'Spitzenkandidaten poker', European Council on Foreign Relations, ecfr.eu July 3, 2019, available at https://www.ecfr.eu/article/commentary spitzenkandidaten poker (accessed 30 October 2019). 
and Eastern Partnership countries. It seems that in international crisis situations, especially when sovereignty was felt threatened, the V4 states tend to intensify collaboration and are likely to seek a common stand. Due to its fluid structures, the Visegrád Group has been more than an 'alliance' but far less than a 'federation'. Lately, though, there are strong signs that it is evolving into a unique development model: the Hungarian PM Orbán declared in December 2019 that it is time to build a new central Europe into the most successful subregion on the continent. ${ }^{66}$

\section{Conclusions}

It has been argued elsewhere that transitional democracies are likely to form and/or join international organisations in order to further their democratic aims and that international organisations support this democratisation process. ${ }^{67}$ This article has claimed, however, that after 15 years of EU membership, institutional attachments have not brought the expected results of European integration or consolidated democracy. Subregionality, on the other hand, has become more important because it provides an intermediary level between the domestic sphere and the wider EU community. Intergovernmental subregional cooperation serves as a shield protecting the individual countries' ability to drive national interest. This presupposes an ability to compromise and adjust national goals together.

The convergences of the V4 countries' policy choices are anchored in the common historical experience of the bipolar geopolitical space: they have been subjects to the same, sometimes rather dramatic changes in the international arena. In addition to these shared experiences, the contiguity of the countries equally matters because it reveals multiple political, economic and cultural interactions and interlinked development. Close connections made the consciousness of the shared

\footnotetext{
${ }^{66}$ Orbán, 'Hungary ready to build a new central Europe', Daily News Hungary 14 December 2019, available at https://dailynewshungary.com/orban-hungary-ready-to-build-new-central-europe/ (accessed 30 January 2020).

${ }^{67}$ Paul Poast and Johannes Urpelainen, Organising Democracy: How International Organisations Assist New Democracies (Chicago: University of Chicago Press, 2018); Daniella Donno, "Who Is Punished? Regional Intergovernmental Organizations and the Enforcement of Democratic Norms," International Organization 64, no. 4 (2010): 593-625.
} 
experience clearer, which eventually magnified the subregional angle. Hence, symbolic-informal relations played a more important role than institutional connectedness. This article further argued that, in contrast to mainstream literature, the East Central European countries did not go through profound changes after 1989. Instead, a core understanding of the need for their alliances emerged long before, rooted in the $19^{\text {th }}$ century and still more so in the years following the First World War. Historical legacies can likewise be detected after the 1990s, when parallel cooperation patterns emerged as trying to find the best formation to drive common goals. While the combination of countries changed in various subregional organisations over the decades, the East Central European states nevertheless often returned to the basic unit of the Visegrád alliance. This subregional entity seems to provide multiple means to maintain sovereignty - especially by applying common development models which makes stronger institutional structures all but unnecessary. 